\title{
Determinanty rozwoju rynku crowdfundingu inwestycyjnego w Europie
}

\begin{abstract}
Determinants of investment crowdfunding market development in Europe: The aim of this paper is to investigate the link between regulations and size of country-level investment crowdfunding markets in Europe. The author discusses the outlook and potential drivers behind the size of investment crowdfunding markets across European countries, with deeper insight into a leading market of the United Kingdom. The conclusions are supported by a quantitative analysis. Key findings indicate that regulatory aspects of investment crowdfunding correlate, on average, stronger with market size than non-regulatory factors. Besides, the size of population matters for crowdfunding market volumes, and British regulatory framework for investment crowdfunding appears as an attractive role model to consider in Poland.
\end{abstract}

Słowa kluczowe: crowdfunding, crowdfunding inwestycyjny, rynek crowdfundingu, finansowanie MŚP, finansowanie innowacji

Keywords: crowdfunding, investment crowdfunding, crowdfunding market, SME financing, financing innovation

* Doktorant w Kolegium Gospodarki Światowej Szkoły Głównej Handlowej w Warszawie, radca Szefa Kancelarii Prezesa Rady Ministrów, członek Rady Nadzorczej Polskiej Agencji Inwestycji i Handlu SA; e-mail: tomasz.piotr.wisniewski@gmail.com.

\section{Wstęp}

Innowacje oparte na rozwijających się technologiach są dynamicznym zjawiskiem kształtującym krajobraz finansów ${ }^{1}$. Takie innowacje w finansach wywarły już widoczny wpływ na słowotwórstwo, rozszerzając terminologię branży finan-

1 PwC, Financial Services Technology 2020 and Beyond: Embracing Disruption, 2016, https://www.pwc.com/gx/en/financial-services/assets/pdf/technology2020-and-beyond.pdf/ [dostęp: 20 października 2018 r.]. 
sowej o pojęcia „fintech”, „insurtech” czy „regtech”2. Jednym z owoców innowacji w finansach jest model finansowania społecznościowego (ang. crowdfunding) ${ }^{3}$, który powstał dzięki technologii powszechnego internetu i umożliwionych przez niego płatności internetowych.

Przyczyn pojawienia się finansowania społecznościowego, oprócz samej technologii jako fundamentu tej innowacji, można upatrywać także w zmieniającej się filozofii społecznej związanej z gospodarką współdzielenia (sharing economy) sensu largo, tj. dzielenia dostępu do dóbr i usług, w tym kanałami technologicznymi ${ }^{4}$. Dzięki megatrendom globalizacji i rewolucji technologicznej proces „dzielenia się," np. informacją czy zasobami, stał się możliwy w rozmaitych aspektach życia, bez względu na fizyczne bariery i odległości między ludźmi. Finansowanie społecznościowe jest przykładem tego, że dzielić można także usługi finansowania, które przez wieki były głównie domeną lichwiarzy, banków i rynków kapitałowych. Należy jednak wskazać, że w przypadku innowacji finansowych ich rozwój i funkcjonowanie ${ }^{5}$ może być determinowane - oprócz trendów społeczno-gospodarczych - także lub przede wszystkim przez regulacje, co zostało zauważone jeszcze $\mathrm{w} \mathrm{XX}$ wieku' ${ }^{6}$. W konsekwencji regulacjom można przypisywać, oprócz roli ostrożnościowej, także rolę stymulanty. Konkretyzując rolę regulacji w rozwoju innowacji poprzez przykład szczególnego modelu finansowania społecznościowego, tj. crowdfundingu inwestycyjnego ${ }^{7}$, można pokusić się o uwagę, że poziom rozwoju tego rynku jest $\mathrm{m}$.in. skorelowany $\mathrm{z}$ obecnością i zaawansowaniem dedykowanych regulacji w jego zakresie, które go stymulują lub legitymizują.

$\mathrm{W}$ artykule zostanie przedstawiona weryfikacja istnienia podstaw do przyjęcia hipotezy o współzależności między wielkością rynku crowdfundingu inwestycyjnego w poszczególnych państwach Europy, a obecnymi w dyskusjach

${ }^{2}$ Liczba rekordów dla hasła „fintech” w wyszukiwarce google.pl to ponad $69 \mathrm{mln}$. Dla hasel „insurtech" i „regtech” to odpowiednio niemal $3 \mathrm{mln}$ i ponad $1 \mathrm{mln}$.

3 Termin „finansowanie społecznościowe” oraz neologiczny termin „crowdfunding” są używane w opracowaniu zamiennie.

${ }^{4}$ M. Ertz, F. Durif, M. Arcand, A conceptual perspective on collaborative consumption, „AMS Rev” 2018 nr 7, s. 1-15, https://doi.org/10.1007/s13162-018-0121-3/.

Autor wskazuje na rozwój i funkcjonowanie innowacji, a nie na powstanie innowacji, ze względu na założenie, że do powstania innowacji finansowych niezbędni są innowatorzy, innowacyjne społeczeństwo i trendy społeczno-gospodarcze, a regulacje pojawiają się na późniejszym etapie, tj. legalizacji, rozwoju i funkcjonowania tych innowacji.

6 M. Miller, Financial Innovation: The Last Twenty Years and the Next, „Journal of Financial and Quantitative Analysis" 1986, nr 21(4), s. 459-471, https://doi.org/10.2307/2330693/.

7 Terminy „crowdfunding inwestycyjny”, „,inwestycyjne finansowanie społecznościowe”, „finansowanie społecznościowe w modelu inwestycyjnym” oraz „inwestycyjny model finansowania społecznościowego" są używane w opracowaniu zamiennie. Jest to propozycja autora dla nazwania zjawiska określanego w literaturze angielskim terminem equity crowdfunding lub investment crowdfunding. 
przedmiotu czynnikami, w tym o charakterze regulacyjnym. Tak więc weryfikacji będą poddane również współzależności dotyczące dedykowanych regulacji. Celem artykułu jest identyfikacja najistotniejszych czynników korelujących z rozwojem (wielkością) rynku crowdfundingu inwestycyjnego.

Autor, po przeglądzie wielkości rynków finansowania społecznościowego w modelu inwestycyjnym w Europie, usystematyzuje regulacyjne i „nieregulacyjne" czynniki wpływające na rynek takiego finansowania, które są obecne w dyskusjach. Zidentyfikowane czynniki stanowią podstawę badania empirycznego przeprowadzonego przez autora, które jest omówione w dalszej części artykułu. Badanie obejmuje analizę korelacji między szacunkową wielkością rynków crowdfundingu inwestycyjnego w poszczególnych państwach Europy a siedmioma czynnikami w tych państwach: obecności dedykowanych regulacji crowdfundingowych (sensu largo), dojrzałości regulacji crowdfundingu inwestycyjnego (sensu stricto), obecności zachęt fiskalnych oraz wartości PKB per capita, liczby ludności, odsetka użytkowników internetu i odsetka użytkowników płatności mobilnych w poszczególnych państwach. Rozdział „Wnioski dla Polski” zawiera zarys rekomendacji dla legislacji i nadzoru finansowego, dotyczących aspektu regulacji crowdfundingowych. Wnioski zostały sformułowane na podstawie badania przeprowadzonego dla ewentualnego uprawdopodobnienia wsparcia rozwoju polskiego rynku crowdfundingu inwestycyjnego regulacjami. Należy podkreślić, że autor nie postuluje zasadności wsparcia rozwoju rynku crowdfundingu inwestycyjnego w Polsce regulacjami, a jedynie wskazuje na potencjalne rozwiązania, które mogłyby takie wsparcie uprawdopodobnić.

\section{Przegląd wielkości rynków crowdfundingu inwestycyjnego w Europie}

Finansowanie społecznościowe, określane neologicznym terminem „crowdfundingu”, oznacza zjawisko finansowania środkami zebranym w ,internetowym tłumie". Termin powstał najprawdopodobniej w 2006 r., natomiast sama koncepcja crowdfundingu została zapoczątkowana niemal dekadę wcześniej przez zespoły muzyczne i producentów filmowych ${ }^{8}$. Ocenia się jednak, że właściwy rozwój crowdfundingu przypadał na lata 2005-2008, kiedy powstawały crowdfundingowe platformy internetowe, takie jak kickstarter.com'. Jednym z modeli crowdfundingu jest crowdfunding inwestycyjny, w którym uczestnicy, jako drobni inwestorzy $\mathrm{z}$,internetowego tłumu”, przekazują swoje środki finansowe na finansowanie danych przedsięwzięć (przedsiębiorstw), otrzymując w zamian udziałowe papiery wartościowe w podmiocie podejmującym się przedsięwzięcia

8 D.T. Dziuba, Rozwój systemów crowdfundingu - modele, oczekiwania i uwarunkowania, „Problemy Zarządzania” 2012, nr 10(3), s. 83-103.

9 Ibidem, s. 84. 


\section{Wykres 1. Szacunkowa wielkość rynków crowdfundingu inwestycyjnego w państwach UE i Szwajcarii}

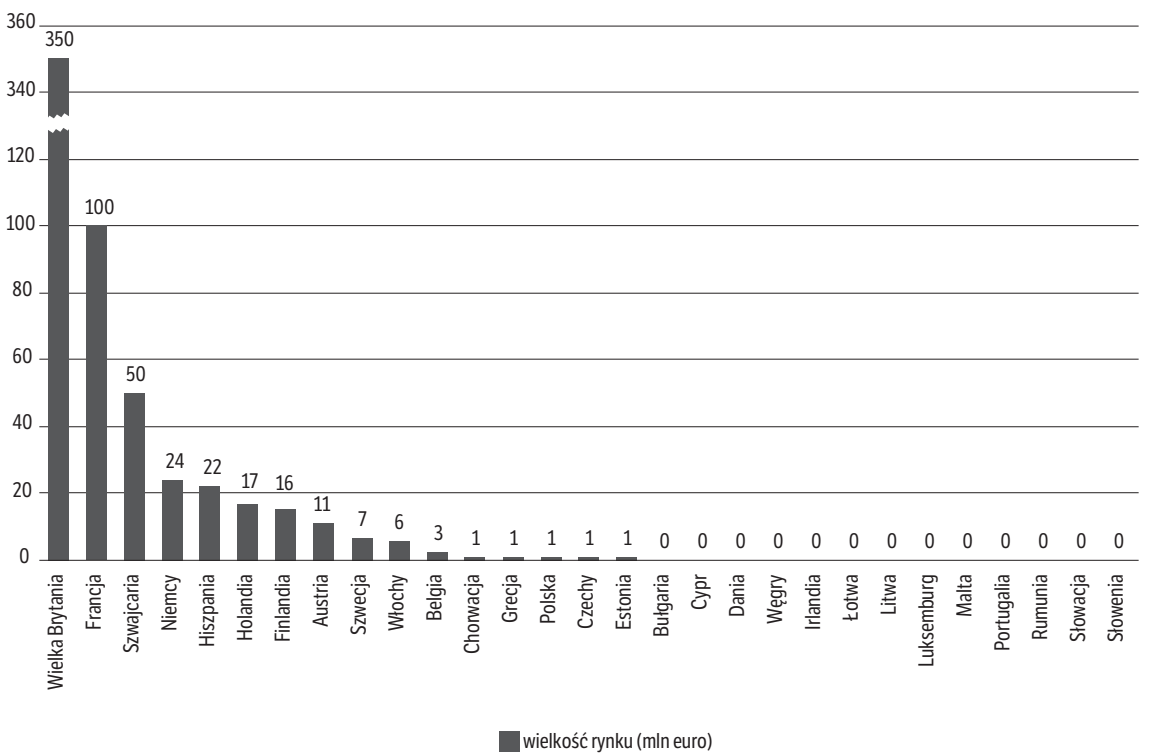

Źródło: wielkości szacunkowe na podstawie raportu Komisji Europejskiej Identifying market and regulatory obstacles to cross-border development of crowdfunding in the EU, grudzień 2017; raportu European Crowdfunding Network Review of Crowdfunding Regulation 2017 oraz raportu Uniwersytetu w Lucernie Crowdfunding Monitoring Switzerland 2017. Dla danych opublikowanych w walucie innej niż euro (Wielka Brytania, Szwajcaria) wielkości przeliczone odpowiednio na podstawie kursu walutowego 1,125 euro/funt brytyjski oraz 0,855 euro/frank szwajcarski.

(przedsiębiorstwie). Wszystko odbywa się za pośrednictwem platform opartych na technologicznych możliwościach powszechnej dostępności zawierania kontraktów oraz dokonywania płatności internetowych. Tak więc crowdfunding inwestycyjny to model, gdzie gratyfikacją za udzielone finansowanie jest przekazanie (sprzedaż) praw własności. Wskazuje się jednak, że oprócz udziałowych papierów wartościowych, zakres ewentualnych korzyści dla inwestorów może być szerszy, obejmując np. upusty w zakupie produktów lub usług związanych z przedsięwzięciem. Takie gratyfikacje są powodem pojawiania się głosów, że crowdfunding inwestycyjny nie jest inwestycją, a połączeniem inwestycji i konsumpcji, gdzie decyzja odnośnie do finansowania danego przedsięwzięcia nie jest decyzją stricte inwestycyjną ${ }^{10}$. Należy wskazać, że crowdfunding inwesty-

10 A. Torchała, Equity crowdfunding dla początkujących, „Puls Biznesu” z 25 października 2018 r., https://www.pb.pl/equity-crowdfunding-dla-poczatkujacych-943696/ [dostęp: 28 października 2018 r.] 
cyjny jest w niektórych państwach najszybciej rozwijającym się modelem finansowania społecznościowego. Szacuje się, że globalna wartość inwestycyjnego finansowania społecznościowego stanowiła w 2016 r. blisko 8\% wartości całego światowego rynku crowdfundingu ${ }^{11}$.

Zakres analizy dotyczącej Europy obejmuje państwa Unii Europejskiej i Szwajcarię. $Z$ uwagi na heterogeniczność rynków crowdfundingu, rozproszony charakter informacji i brak oficjalnych lub zunifikowanych statystyk, badanie zostało przeprowadzone metodą desktop research. Wykres 1 przedstawia szacunkową wielkość rynków crowdfundingu inwestycyjnego w analizowanych państwach. Wielka Brytania ${ }^{12}$ jest jednoznacznie największym rynkiem crowdfundingu inwestycyjnego (wartość co najmniej $350 \mathrm{mln}$ euro), ponadtrzykrotnie i siedmiokrotnie większym od, odpowiednio, drugiej w zestawieniu Francji (co najmniej $100 \mathrm{mln}$ euro wartości) i trzeciej Szwajcarii (ok. $50 \mathrm{mln}$ euro). Te trzy rynki stanowią ponad $82 \%$ wartości całego finansowania społecznościowego w modelu inwestycyjnym dla Europy. Na drugim biegunie znajduje się 13 państw, gdzie na podstawie dostępnych danych nie zidentyfikowano rynku crowdfundingu inwestycyjnego, a dla 5 kolejnych (w tym dla Polski) dostępne informacje sugerują śladowe istnienie takiego rynku, o wartości poniżej $1 \mathrm{mln}$ euro.

\section{Czynniki rozwoju rynków crowdfundingu inwestycyjnego w Europie}

Analizując czynniki rozwoju rynku crowdfundingu inwestycyjnego, autor w pierwszej kolejności skupił się na weryfikacji istnienia podstaw do przyjęcia hipotezy w części dotyczącej regulacji. Współzależność między funkcjonowaniem i rozwojem (wielkością rynku) crowdfundingu inwestycyjnego a aspektami regulacyjnymi jest ilustrowana zestawieniem wielkości tych rynków z informacjami dotyczącymi obecności prorozwojowych dedykowanych regulacji dla finansowania społecznościowego sensu largo $^{13}$ na poszczególnych rynkach (wykres 2). Według informacji dostępnych na koniec 2017 r. regulacje dotyczące zjawiska crowdfundingu obowiązywały w 11 państwach UE. Na podstawie danych szacunkowych za ostatnie kilka lat państwa te reprezentują ponad $98 \%$ całego rynku crowdfundingu inwestycyjnego w UE (ponad 90\% w UE łącznie ze Szwajcarią), co uprawdopodabnia przypuszczenie, że regulacje dotyczące finansowania społecznościowego, nawet jeśli dotyczą szerokiego rozumienia tego typu finansowania w różnych modelach, sprzyjają rozwojowi crowdfundingu

${ }_{11}$ Ponad 70\% rynku przypadło na model peer-to-peer lending, czyli crowdfunding pożyczkowy. Zob. raport Global Crowdfunding Market 2017-2021 dostępny w serwisie EMIS.

${ }_{12} \mathrm{Z}$ uwagi na odroczony termin brexitu Wielka Brytania jest wciąż formalnie członkiem UE. W opracowaniu Wielka Brytania oznacza Zjednoczone Królestwo Wielkiej Brytanii i Irlandii Północnej (UK).

${ }_{13} \mathrm{Tj}$. finansowania społecznościowego w różnych modelach, np. charytatywnym (składki, datki), pożyczkowym czy inwestycyjnym. 
inwestycyjnego. W państwach niemających tego typu dedykowanych regulacji rynek crowdfundingu (bądź niektóre jego modele) może funkcjonować na podstawie przepisów ogólnych lub być prawnie ograniczony.

\section{Wykres 2. Szacunkowa wielkość rynków crowdfundingu inwestycyjnego na tle obec- ności dedykowanych regulacji dotyczących crowdfundingu}

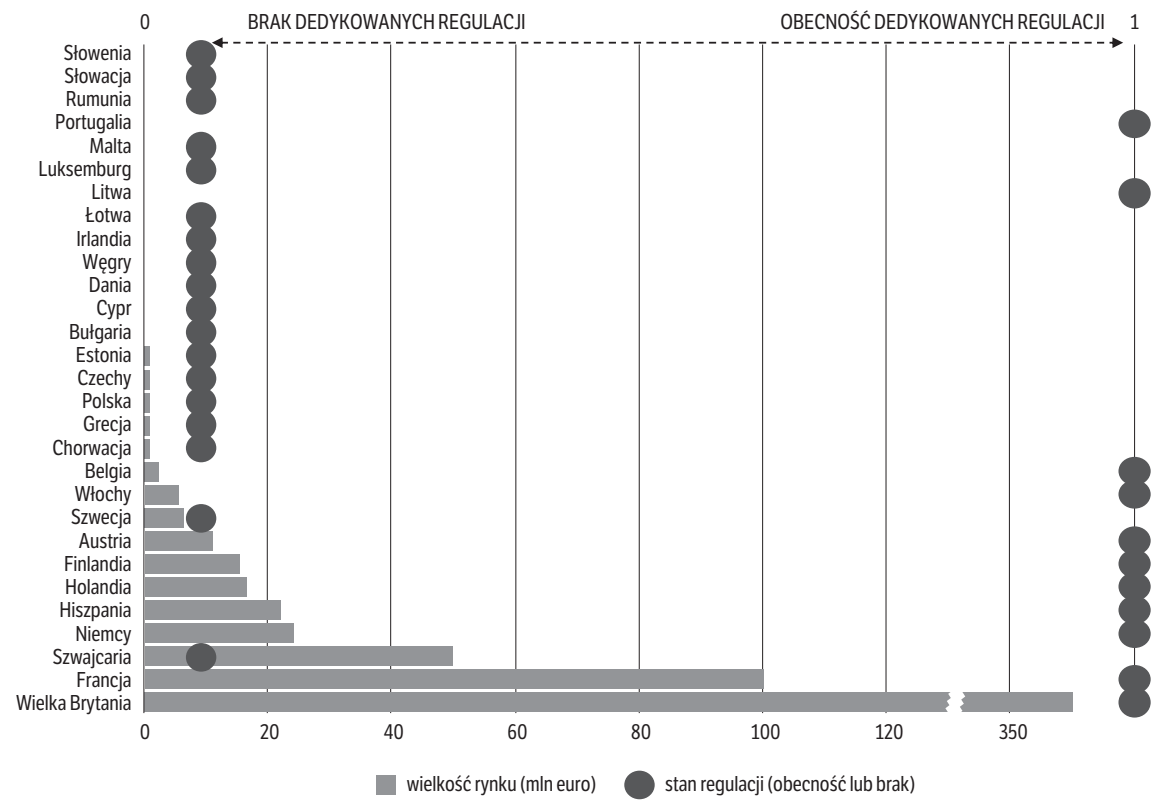

Źródło: szacunkowe wielkości rynków i obecność dedykowanych regulacji dotyczących crowdfundingu zob. źródło dla wykresu 1.

Obecność dedykowanych regulacji sensu largo jest pierwszym czynnikiem (czynnik 1) analizowanym w badaniu omówionym w dalszej części artykułu.

Kolejnym krokiem dla weryfikacji istnienia podstaw do przyjęcia wskazanej hipotezy jest zawężenie obszaru regulacji do crowdfundingu inwestycyjnego i jego ponowne zestawienie z wielkością poszczególnych rynków (wykres 3). Takie zawężenie zostało oparte na indeksie AFMI (Alternative Finance Maturity Index), mierzącym poziom rozwoju (dojrzałości) finansów alternatywnych wybranych państw europejskich w aspektach regulacyjnych i nieregulacyjnych, $\mathrm{w}$ tym także mierzącym dojrzałość regulacji crowdfundingu inwestycyjnego ${ }^{14}$. Gradacja indeksu AFMI implikuje 3 poziomy dojrzałości regulacji. Wobec

${ }^{14}$ Metodologia pomiaru indeksu AFMI zob. Raport Current State of Crowdfunding in Europe, Crowdfunding Hub, 2016. 
czego 6 spośród analizowanych rynków charakteryzuje się dużym stopniem komparatywnego, czyli porównawczego, rozwoju (dojrzałości) regulacji dla inwestycyjnego modelu finansowania społecznościowego (ok. 72\% łącznego rynku crowdfundingu inwestycyjnego w UE i Szwajcarii). Następnie 22 państwa charakteryzują się średnim poziomem rozwoju takich regulacji (ok. 28\% łącznego rynku), a tylko w jednym państwie poziom rozwoju regulacji oceniono na niski. Podobnie jak w przypadku regulacji dotyczących szerokiego znaczenia crowdfundingu, prawdopodobne wydaje się przypuszczenie, że obecność (poziom rozwoju) regulacji dotyczących stricte crowdfundingu inwestycyjnego sprzyja rozwojowi takiego modelu finansowania. W Danii niska dojrzałość prorozwojowych regulacji dla crowdfundingu inwestycyjnego wiąże się z faktem, że inwestycyjne finansowanie społecznościowe jest tam prawnie ograniczone.

Wykres 3. Szacunkowa wielkość rynków crowdfundingu inwestycyjnego na tle poziomu rozwoju regulacji dotyczących crowdfundingu inwestycyjnego

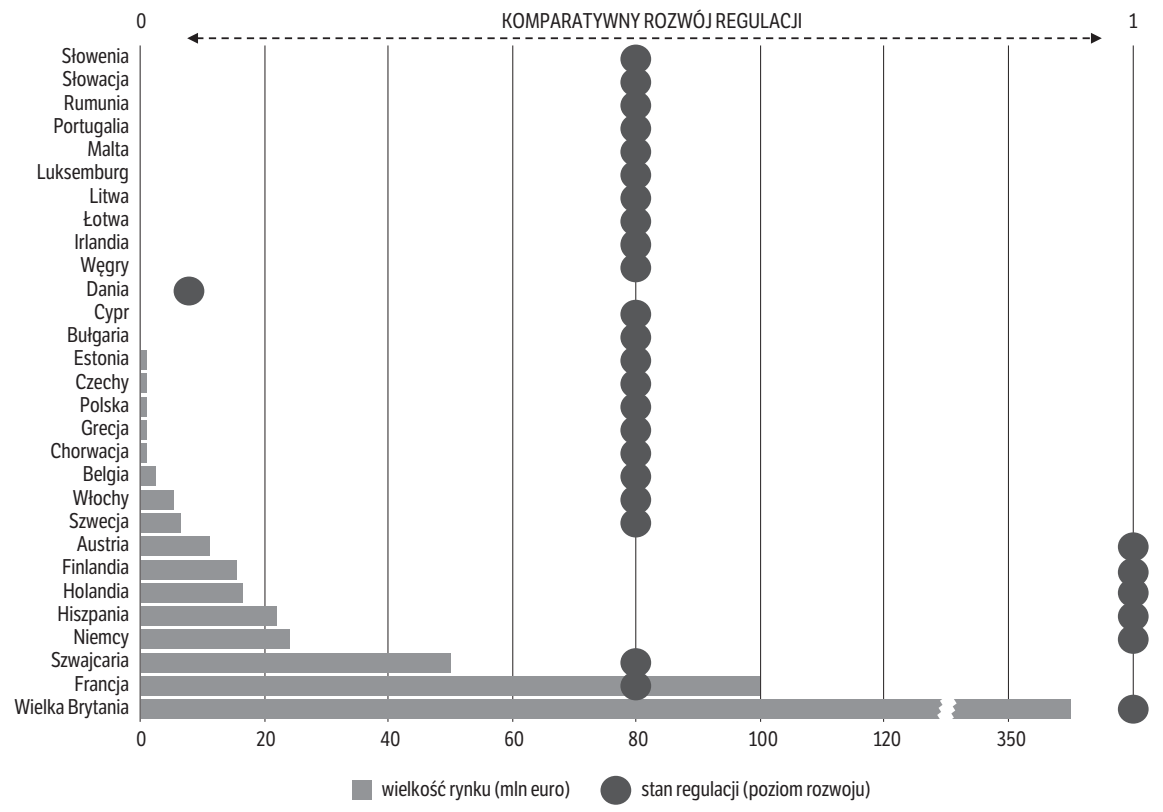

Źródło: jak dla wykresu 2.

Rozwój regulacji sensu stricto jest drugim czynnikiem (czynnik 2) analizowanym w badaniu omówionym w dalszej części artykułu. Czynnik ma trzystopniową skalę (duży, średni i niski stopień komparatywnego rozwoju regulacji), implikowaną przez trzystopniową gradację indeksu AFMI. 
Kontynuując weryfikację istnienia podstaw do przyjęcia omawianej hipotezy w części dotyczącej regulacji, zasadne wydaje się głębsze zbadanie regulacyjnej kwestii zachęt fiskalnych związanych z crowdfundingiem. Należy wskazać, że brak bezpośrednich regulacji dotyczących sfery podatkowej, skutkujących stosowaniem przepisów ogólnych zgodnie z istniejącymi konstrukcjami, dopasowywanych do konkretnego finansowania, może wprowadzać niepewność ${ }^{15}$. Taka niepewność może natomiast stanowić destymulantę, zarówno dla strony popytowej, jak i podażowej finansowania społecznościowego w modelu inwestycyjnym, czego efektem jest słabszy rozwój takiego finansowania lub jego brak. Niemniej formułowanie takiego wniosku na podstawie danych $\mathrm{z}$ badanych państw jest utrudnione, gdyż horyzontalny przegląd kwestii podatkowych w obszarze crowdfundingu sugeruje, że zachęty fiskalne funkcjonują w regulacjach jedynie dwóch państw - Wielkiej Brytanii i Belgii. Przy czym, o ile w odniesieniu do rynku brytyjskiego można przypuszczać i dowodzić - ze względu na relatywnie największą skalę rynku - że takie zachęty są stymulantą, o tyle dla rynku belgijskiego takie przypuszczenie może być przedwczesne, przez wzgląd na niewielką (jeszcze) szacunkową skalę rozwoju inwestycyjnego modelu finansowania społecznościowego ${ }^{16}$. Taka niewielka skala, pomimo zachęt fiskalnych, może być też efektem (relatywnie) niewielkiej liczby ludności Belgii ${ }^{17}$. Zachęty fiskalne są trzecim czynnikiem (czynnik 3) analizowanym w badaniu, z zastrzeżeniem, że miarodajność wnioskowania płynącego z tego czynnika może być ograniczona.

Czynnikami egzogenicznymi rozwoju finansowania społecznościowego w modelu inwestycyjnym mogą być, na co wskazują eksperci, m.in. wielkość gospodarki, mierzona w szczególności liczbą ludności i PKB per capita analizowanych państw ${ }^{18}$. Znaczenie tych czynników dla rozwoju crowdfundingu inwestycyjnego ilustrują wykresy 4 i 5, zawierające zestawienie wielkości poszczególnych rynków takiego finansowania względem odpowiednio PKB per capita i liczby ludności poszczególnych państw.

15 Na podstawie FutureTech.legal (Prawo a Crowdfunding, czyli finansowanie społecznościowe), 2018, https://www.futuretech.legal/crowdfunding-a-prawo/ [dostęp: 10 stycznia 2019 r.].

${ }_{16}$ Około 3 mln euro, zob. wykres 1 i tabela 2.

17 Zob. czynnik $5 \mathrm{w}$ dalszej części artykułu.

18 Są to czynniki uwzględniane i wzmiankowane w raportach dotyczących statystyk finansowania społecznościowego, m.in. w raporcie Komisji Europejskiej Identifying market and regulatory obstacles to cross-border development of crowdfunding in the EU, grudzien 2017 r., raporcie European Crowdfunding Network Review of Crowdfunding Regulation 2017 oraz raporcie Uniwersytetu w Lucernie Crowdfunding Monitoring Switzerland 2017, w którym (umiarkowana) wielkość gospodarki Szwajcarii określana jest mianem „niekorzyści skali” (economy-of-scale disbenefit). 


\section{Wykres 4. Zestawienie wielkości poszczególnych rynków crowdfundingu inwestycyj- nego względem PKB per capita poszczególnych państw}
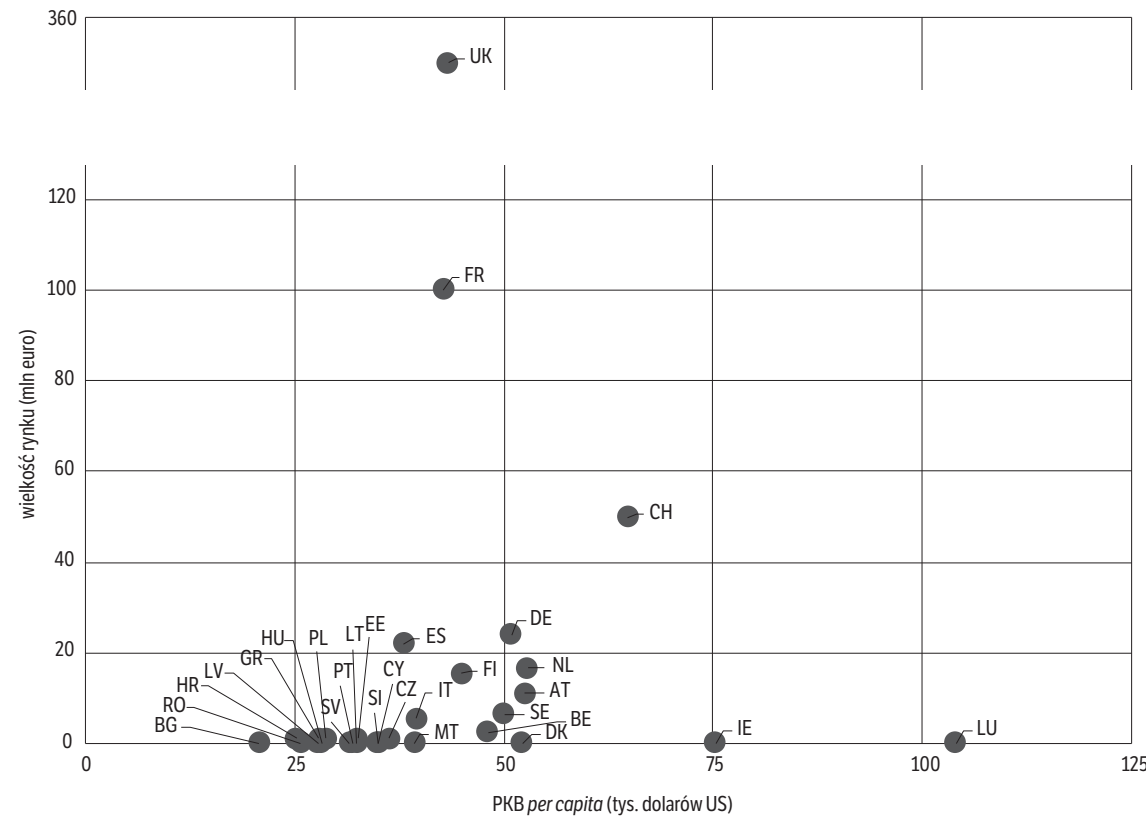

Źródło: szacunkowe wielkości rynków zob. przypis 1 w tabeli 2. Dane dotyczące PKB per capita na podstawie OECD Data (dla Chorwacji na podstawie World Bank Data), dane za rok 2017 w parytecie siły nabywczej w dolarach amerykańskich (tys. dolarów US), ceny stałe. Symbole państw oznaczają odpowiednio w kolejności alfabetycznej: AT (Austria), BE (Belgia), BG (Bułgaria), CH (Szwajcaria), CY (Cypr), CZ (Czechy), DE (Niemcy), DK (Dania), EE (Estonia), ES (Hiszpania), FI (Finlandia), FR (Francja), GR (Grecja), HR (Chorwacja), HU (Węgry), IE (Irlandia), IT (Włochy), LT (Litwa), LU (Luksemburg), LV (Łotwa), MT (Malta), NL (Holandia), PL (Polska), PT (Portugalia), RO (Rumunia), SE (Szwecja), SI (Słowenia), SV (Słowacja), UK (Wielka Brytania).

Produkt krajowy brutto per capita dla dwóch największych rynków crowdfundingu inwestycyjnego (Wielkiej Brytanii i Francji, odpowiednio 43,4 tys. dolarów US i 42,9 tys. dolarów US) kształtuje się nieznacznie powyżej średniej wartości tego wskaźnika dla analizowanych państw (42 tys. dolarów US). Wartość krajowych rynków crowdfundingu inwestycyjnego jest niższa dla 10 państw $\mathrm{z}$ wyższym poziomem $\mathrm{PKB}$ per capita oraz dla 17 państw z niższym $\mathrm{PKB}$ per capita. Wydaje się, że nie ma wyraźnej zależności między wielkością rynków crowdfundingu inwestycyjnego a przeciętną wysokością PKB w społeczeństwie. Taka obserwacja jest tym sugestywniejsza, że crowdfunding inwestycyjny praktycznie nie funkcjonuje zarówno w państwie o najniższym dochodzie per capita (Bułgaria), jak i w państwie o najwyższym dochodzie przypadającym na mieszkańca (Luksemburg). 
Wykres 5. Zestawienie wielkości poszczególnych rynków crowdfundingu inwestycyjnego względem liczby ludności poszczególnych państw
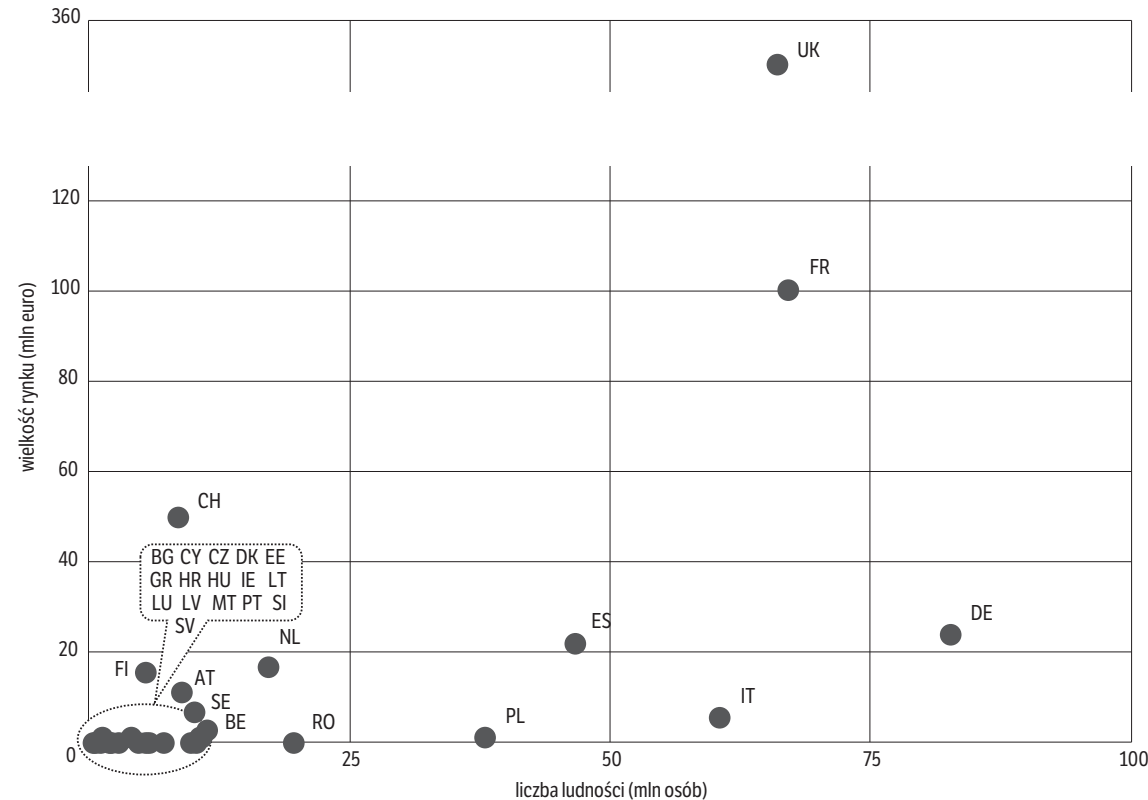

Źródło: szacunkowe wielkości rynków zob. przypis 1 w tabeli 2. Dane dotyczące liczby ludności na podstawie World Bank Data, dane za 2017 r. w mln osób. Symbole państw jak pod wykresem 4.

Liczba ludności dla dwóch największych rynków crowdfundingu inwestycyjnego (Wielkiej Brytanii i Francji, odpowiednio ok. $66 \mathrm{mln}$ osób i ok. $67 \mathrm{mln}$ osób) kształtuje się znacznie powyżej średniej wartości ludności analizowanych państw (18 mln osób). Są to państwa należące do grupy najludniejszych (obok Niemiec) państw europejskich. Wśród pięciu państw z największymi rynkami crowdfundingu inwestycyjnego tylko jeden (Szwajcaria) cechuje relatywnie niska liczba ludności (poniżej $10 \mathrm{mln}$ osób), podczas gdy pozostałe cztery państwa mają ponad $45 \mathrm{mln}$ ludności. Wydaje się więc, że można zaobserwować pewną współzależność między wielkością rynków crowdfundingu inwestycyjnego, a ludnością tego rynku (państwa). Polska z liczbą ludności ok. $38 \mathrm{mln}$ jest jedynym dużym państwem (ludność powyżej $20 \mathrm{mln}$ ), w którym wielkość rynku finansowania społecznościowego w modelu inwestycyjnym jest niewielka.

Wartość PKB per capita oraz liczba ludności poszczególnych państw są kolejnymi czynnikami (czynnik 4 i 5) analizowanymi w badaniu jako makroekonomiczne czynniki egzogeniczne, które potencjalnie warunkują rozwój i funkcjonowanie finansowania społecznościowego w modelu inwestycyjnym. 


\section{Wykres 6. Zestawienie wielkości poszczególnych rynków crowdfundingu inwestycyj- nego względem odsetka użytkowników internetu w poszczególnych państwach}
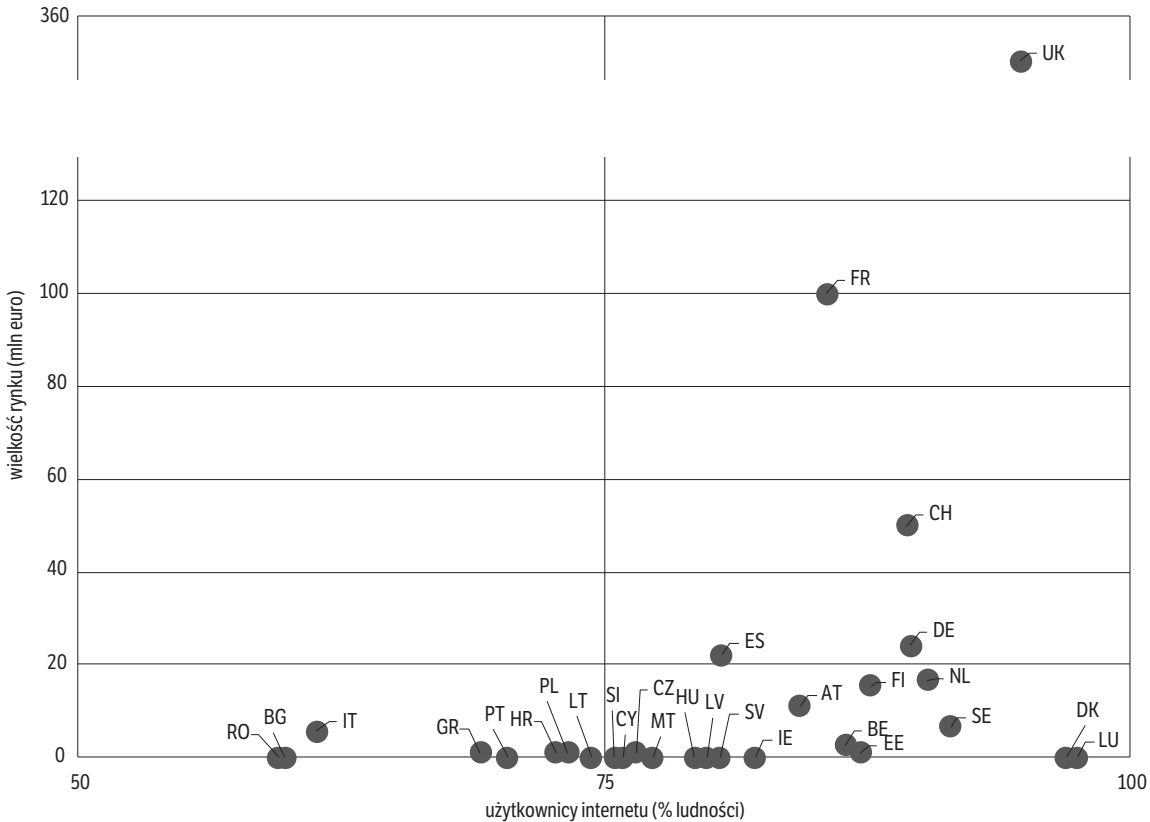

Źródło: szacunkowe wielkości rynków zob. przypis 1 w tabeli 2. Dane dotyczące odsetka użytkowników internetu na podstawie raportu Światowego Forum Ekonomicznego Global Competitiveness Report 2017-2018, dane dla wskaźnika „Użytkownicy internetu” (filar „Gotowości technologicznej”). Symbole państw jak pod wykresem 4.

W dyskusjach i literaturze przedmiotu autorzy wskazują także na inne czynniki o charakterze egzogenicznym - rozwój i stopień powszechności internetu oraz używanie go przez konsumentów (i inwestorów) jako kanału zakupowego (i inwestycyjnego ${ }^{19}$. Niektórzy postulują również, że crowdfunding rozwinął (rozwija) się dzięki systemom płatności jak np. PayPal ${ }^{20}$. Wydaje się więc, że przez pryzmat takich postulatów kolejnymi czynnikami niniejszej dyskusji powinny być mierniki powszechności internetu oraz powszechności płatności internetowych czy mobilnych. Znaczenie tych czynników w kontekście rozwoju crowdfundingu inwestycyjnego analizowane jest również za pomocą ilustracji (wykresy 6

19 Na przykład w raporcie dla Komisji Europejskiej pt. Crowdfunding from an investor perspective, 2015, s. 2; w artykule D. Millera, E-Commerce Is To Borders As Crowdfunding Is To Wall Street, „Forbes” z 16 marca 2015 r., https://www.forbes.com/sites/theyec/2015/03/16/e-commerce-is-to-borders-as-crowdfunding-is-to-wall-street/\#7f1f6cfa1f29/ [dostęp: 24 listopada $2018 \mathrm{r}$.].

${ }^{20}$ M. Carvajal, J.A. García-Avilés, J.L. González, Crowdfunding and non-profit media, „Journalism Practice” March 2012, https://doi.org/10.1080/17512786.2012.667267/. 
i 7), zawierających zestawienie wielkości poszczególnych rynków crowdfundingu inwestycyjnego względem odpowiednio odsetka użytkowników internetu oraz odsetka użytkowników płatności mobilnych w poszczególnych państwach.

Crowdfunding inwestycyjny praktycznie nie funkcjonuje zarówno w państwie o najniższym odsetku użytkowników internetu (Rumunia), jak i w państwie o najwyższym odsetku użytkowników internetu (Luksemburg), podobnie jak w przypadku wartości PKB per capita. Warto jednak zauważyć zależność, że w państwach, gdzie odsetek użytkowników internetu jest poniżej pewnego poziomu (ok. 80\%), crowdfunding inwestycyjny, z wyjątkiem Włoch, praktycznie nie funkcjonuje. Natomiast wśród państw, dla których odsetek użytkowników internetu jest powyżej tego poziomu, większość ma rynki crowdfundingu inwestycyjnego o wartości powyżej $10 \mathrm{mln}$ euro.

\section{Wykres 7. Zestawienie wielkości poszczególnych rynków crowdfundingu inwestycyj-} nego względem odsetka użytkowników płatności mobilnych w wybranych państwach
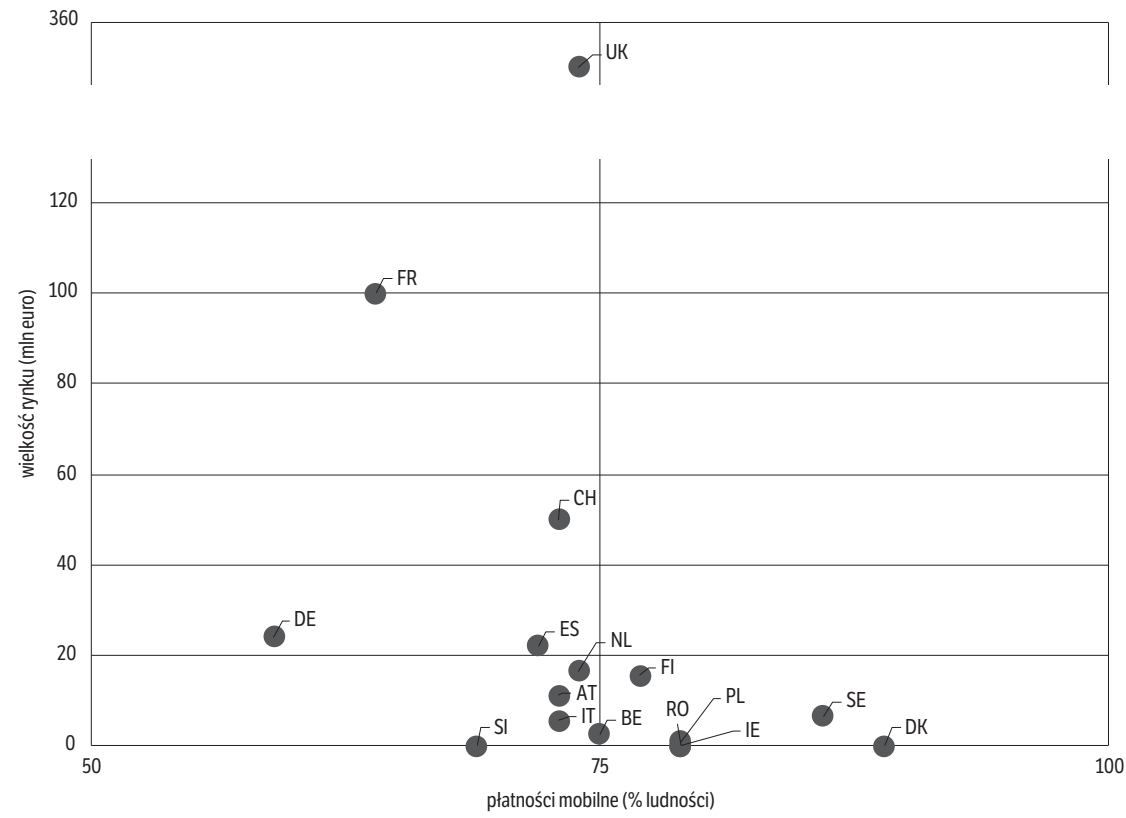

Źródło: szacunkowe wielkości rynków zob. przypis 1 w tabeli 2. Dane dotyczące odsetka użytkowników płatności mobilnych na podstawie Visa Digital Payments study, 2016. Dane dostępne dla wybranych rynków. Symbole państw jak pod wykresem 4.

Precyzyjna analiza aspektu płatności internetowych jest utrudniona z uwagi na brak powszechnych paneuropejskich statystyk. Raporty Europejskiego Banku Centralnego (EBC) nie wyodrębniają jednoznacznie i holistycznie tego 
typu płatności ${ }^{21}$. Natomiast, dane dotyczące płatności mobilnych opublikowane przez Visę̨ ${ }^{22}$, dostępne dla 16 z 29 analizowanych rynków, nie ukazują wyraźnej zależności między wielkością rynków crowdfundingu inwestycyjnego a zadeklarowanymi preferencjami użytkowników w korzystaniu z płatności mobilnych. Wykres 7 wskazuje, że wysoki odsetek użytkowników płatności mobilnych nie determinuje wysokiej wartości rynku crowdfundingu inwestycyjnego.

Odsetek użytkowników internetu oraz odsetek użytkowników płatności mobilnych są kolejnymi czynnikami (czynnik 6 i 7) analizowanymi w badaniu jako czynniki egzogeniczne o charakterze konsumenckim (społecznym).

Autor uważa, że istotnym czynnikiem wpływającym na rozwój rynku crowdfundingu inwestycyjnego może być także specyfika systemu finansowego gospodarki. Jako że inwestycyjne finansowanie społecznościowe stanowi element szeroko pojętego rynku kapitałowego, jego rozwój wydaje się bardziej naturalny w gospodarkach o systemie anglosaskim. Są to gospodarki oparte głównie na finansowaniu poprzez rynki kapitałowe, w przeciwieństwie do kontynentalnego modelu finansowego gospodarki, opartego przede wszystkim na finansowaniu przez sektor bankowy. Czynnik systemu finansowego nie jest analizowany explicite w badaniu empirycznym autora tak jak poprzednie czynniki, ale badanie ten czynnik uwzględnia. $\mathrm{Z}$ uwagi na systemowy charakter uwzględnienie to następuje poprzez wyodrębnienie Wielkiej Brytanii, będącej jedyną gospodarką $\mathrm{z}$ wyraźnym systemem anglosaskim ${ }^{23} \mathrm{w}$ badanej grupie państw, oraz omówienie wyników badania zarówno z uwzględnieniem, jak i bez uwzględnienia tego państwa, w celu trafniejszej interpretacji wyników.

Należy podkreślić, że zidentyfikowana grupa czynników nie ma charakteru holistycznego, gdyż można byłoby poszukiwać kolejnych potencjalnych czynników makroekonomicznych i społecznych, np. skłonność do oszczędzania (inwestowania) danego społeczeństwa, aspekty demograficzne, kwestie zaufania społeczeństwa do rynku kapitałowego, szeroko pojęta atrakcyjność jurysdykcji danego rynku dla inwestorów zagranicznych czy stopień przedsiębiorczości i innowacji w życiu społeczno-gospodarczym danego państwa.

${ }^{21}$ Raporty EBC (publikowane w ECB Statistical Data Warehouse) zawierające dane dotyczące płatności nie odzwierciedlają płatności internetowych lub mobilnych. Płatności poprzez pieniądz elektroniczny (electronic money, e-money) są zdefiniowane jako płatności z użyciem określonego nośnika pieniądza i nie oznaczają płatności online.

22 Odsetek badanych konsumentów deklarujących korzystanie z płatności mobilnych. Na podstawie Visa Digital Payments study, 2016. Dane dostępne dla wybranych spośród analizowanych rynków.

${ }^{23}$ Autor przyjmuje, że marginalny rynek crowdfundingu inwestycyjnego w Irlandii uprawnia do nierozstrzygania, na potrzeby niniejszego artykułu, charakterystyki irlandzkiego systemu finansowego i zakwalifikowanie go do modelu kontynentalnego z uwagi na stopień zintegrowania $\mathrm{z}$ europejskim systemem finansowym. 


\section{Największy rynek crowdfundingu inwestycyjnego w Europie - studium przypadku}

Niniejszy podrozdział obejmuje studium przypadku dla rynku brytyjskiego, z zastrzeżeniem że rozwój i funkcjonowanie tego rynku mogą być w znacznym stopniu warunkowane specyfiką brytyjskiego (anglosaskiego) systemu finansowego. Autor jest zdania, że anglosaski system finansowy brytyjskiej gospodarki nie jest jedynym czynnikiem, który uwarunkował dynamiczny rozwój crowdfundingu inwestycyjnego na Wyspach ${ }^{24}$. Dlatego też uważa, że studium przypadku Wielkiej Brytanii może posłużyć dyskusjom prorozwojowym w gospodarkach z systemem kontynentalnym, w tym w Polsce.

Wielka Brytania jest wskazywana jako najszybciej rosnący rynek crowdfundingu inwestycyjnego na świecie zarówno pod względem wartości, jak i liczby kampanii ${ }^{25}$. Nie jest to informacja zaskakująca, gdyż Wielka Brytania plasuje się w czołówkach zestawień dotyczących „głębokości” rynku finansowego czy rozwoju finansów alternatywnych ${ }^{26}$. Ponadto jest to rynek o relatywnie dużej populacji na skalę europejską (66 mln mieszkańców), odnotowujący, mimo niepewności związanej z brexitem, dodatnie saldo migracji ${ }^{27}$ oraz znaczącą obecność podmiotów zagranicznych w brytyjskim obrocie gospodarczym. Wydaje się jednak, że sam fakt, iż Wielka Brytania jest dużym i bardzo rozwiniętym rynkiem finansowym w szerokim ujęciu nie wyczerpuje powodów obserwowanego szybkiego rozwoju crowdfundingu inwestycyjnego. Powszechnie uważa się bowiem, że rozwój zjawiska equity crowdfunding na rynku brytyjskim jest w dużej mierze efektem jasnej struktury regulacji funkcjonujących w Wielkiej Brytanii, które dodatkowo umożliwiają uczestnikom finansowania społecznościowego w modelu inwestycyjnym (czyli inwestorom) korzystanie z ulg podatkowych $^{28}$. Jeszcze w 2015 r. oceniano, że Wielka Brytania jest jedynym rynkiem na świecie posiadającym tak dużą liczbę platform crowdfundingowych o czysto inwestycyjnym charakterze, poprzez które inwestorzy nabyli udziały

${ }^{24}$ Argumentem dla takiego stanowiska jest przykład Stanów Zjednoczonych z anglosaskim systemem finansowym, w których rozwój crowdfundingu inwestycyjnego nie był możliwy przed wprowadzeniem odpowiednich regulacji (JOBS Act).

${ }^{25}$ N. Vulkan, T. Astebro, M. Fernandez Sierra, Equity crowdfunding: A new phenomena, "Journal of Business Venturing Insights" 2016, t. 5, s. 37-49.

26 S. Vismara, Equity Retention and Social Network Theory in Equity Crowdfunding, „SSRN Electronic Journal” September 2015, https://doi.org/10.2139/ssrn.2654325/.

27 Office for National Statistics, Migration Statistics Quarterly Report: November 2018, https://www.ons.gov.uk/peoplepopulationandcommunity/populationandmigration/internationalmigration/bulletins/migrationstatisticsquarterlyreport/november2018/ [dostęp: 20 grudnia 2018 r.].

${ }^{28}$ Equity crowdfunding: A new phenomena, op. cit. 
w setkach podmiotów (przedsięwzięć) ${ }^{29}$. Na wzrost wolumenów crowdfundingu inwestycyjnego w Wielkiej Brytanii nie wydawała się też wpływać niepewność inwestycyjna związana $\mathrm{z}$ brexitem, w przeciwieństwie do np. kondycji napływu bezpośrednich inwestycji zagranicznych, które, jak oceniają eksperci, spadły od momentu referendum w 2016 r. o $19 \%{ }^{30}$.

Według danych z 2017 r. średnia wartość kampanii finansowania społecznościowego w modelu inwestycyjnym osiągała ponad $0,5 \mathrm{mln}$ funtów szterlingów $\left(523 \mathrm{978}^{31}\right.$. Natomiast średnia wartość takiego finansowania dla 20 największych kampanii, które przedstawia tabela 1, wynosiła w $2017 \mathrm{r}$. ponad $3 \mathrm{mln}$ funtów szterlingów. Największe trzy kampanie w 2017 r. to inwestycje opiewające na ok. 5-6 mln funtów szterlingów, czyli więcej niż cała wartość krajowych rynków crowdfundingu inwestycyjnego dla większości państw Europy.

Zważywszy na efektywne roczne limity ${ }^{32}$ inwestycji w kampanie crowdfundingu inwestycyjnego oraz obserwowane średnie wartości tych kampanii, można przypuszczać, że liczebność indywidualnych inwestorów finansowania społecznościowego w modelu inwestycyjnym jest relatywnie duża. Warto jednak zauważyć, że crowdfunding inwestycyjny jest w Wielkiej Brytanii zinstytucjonalizowany, tj. znaczna część inwestorów crowdfundingowych finansujących kampanie o charakterze inwestycyjnym to inwestorzy instytucjonalni (ocenia się, że w 2017 r. to niemal połowa) ${ }^{33}$. Nie zmienia to faktu, że relatywnie duża liczebność inwestorów crowdfundingowych może być potwierdzeniem efektu funkcjonowania wspomnianych zachęt fiskalnych, tj. ulg podatkowych ${ }^{34}$. Nie bez znaczenia w tym efekcie może być też wysoki, jeden z najwyższych w Europie, poziom odsetka użytkowników internetu w Wielkiej Brytanii (niemal 95\% ${ }^{35}$ ).

${ }^{29}$ Equity Retention and Social Network Theory in Equity Crowdfunding, op. cit.

${ }^{30}$ I. Serwicka, N. Tamberi, Not Backing Britain: Brexit vote has reduced foreign direct investment to the UK by 19 per cent, „UK Trade Policy Observatory” z 31 października 2018 r., http://blogs.sussex.ac.uk/uktpo/2018/11/01/brexit-vote-has-reduced-foreign-direct-investment-to-the-uk-by-19-per-cent/.

31 Raport Fundacji Nesta, Crowdfunding and alternative finance in the UK, 2017, https:// www.gov.scot/binaries/content/documents/govscot/publications/minutes/2017/10/expert-advisory-panel-on-the-collaborative-economy-august-2017/documents/f9424fc5-ae974454-87b6-669e36602f13/f9424fc5-ae97-4454-87b6-669e36602f13/govscot\%3Adocument/ [dostęp: 7 listopada 2018 r.].

${ }^{32}$ Limit roczny 100 tys. funtów. Zob. HMRC Guidance, https://www.gov.uk/government/ publications/seed-enterprise-investment-scheme-income-tax-and-capital-gains-tax-reliefs-hs393-self-assessment-helpsheet/hs393-seed-enterprise-investment-scheme-income-tax-and-capital-gains-tax-reliefs-2017/ [dostęp: 25 października 2018 r.].

${ }^{33}$ University of Cambridge, The $5^{\text {th }}$ UK Alternative Finance Industry Report, Cambridge 2018, s. 8.

${ }^{34}$ Equity crowdfunding: A new phenomena, op. cit.

${ }^{35}$ Zob. tabela 2. 
Tabela 1. Zestawienie 20 największych kampanii crowdfundingu inwestycyjnego w Wielkiej Brytanii w 2017 r.

\begin{tabular}{|r|l|c|}
\hline Lp. & Podmiot (inicjatywa) kampanii & $\begin{array}{c}\text { Wartość kampanii } \\
\text { (w mln funtów szterlingów) }\end{array}$ \\
\hline 1 & Seedrs & 6,0 \\
\hline 2 & Hibergene Diagnostics & 5,7 \\
\hline 3 & Hopster & 4,8 \\
\hline 4 & Revolut & 3,9 \\
\hline 5 & Lightpoint Medical & 3,3 \\
\hline 6 & VitaMojo & 3,2 \\
\hline 7 & Keen Home & 2,9 \\
\hline 8 & Bolt Mobility & 2,8 \\
\hline 9 & Peptinnovte & 2,7 \\
\hline 10 & DueDul & 2,6 \\
\hline 11 & Commuter Club & 2,5 \\
\hline 12 & Monzo & 2,5 \\
\hline 13 & Landbay & 2,4 \\
\hline 14 & Cocoon & 2,3 \\
\hline 15 & Den & 2,2 \\
\hline 16 & JustPark & 2,2 \\
\hline 17 & Integumen & 2,1 \\
\hline 18 & Warwick Audio & 2,1 \\
\hline 19 & Griplt & 2,0 \\
\hline 20 & Core Collective & 2,0 \\
\hline Łącznie & 60,2 \\
\hline & & \\
\hline
\end{tabular}

Źródło: na podstawie O. Williams-Grut, The 20 biggest crowdfunding campaigns of 2017, „Businessinsider. com" 31 grudnia 2017 r., https://www.businessinsider.com/20-biggest-crowdfunding-campaigns-of-2017$-2017-12$ ? IR=T/ [dostęp: 1 grudnia 2018 r.].

Platformy crowdfundingowe funkcjonują w Wielkiej Brytanii na zasadach regulowanych przez $\mathrm{FCA}^{36}$. Regulacje obowiązujące od 2014 r. wprowadzily możliwość oferowania (reklamowania) inwestorom indywidualnym, pod pewnymi warunkami, uczestnictwa w kampaniach crowdfundingowych o charakterze inwestycyjnym bez powszechnie obowiązujących ograniczeń (obostrzeń) dotyczących oferowania niektórych papierów wartościowych ${ }^{37}$. W finansowaniu takich kampanii, tj. w nabywaniu udziałowych papierów wartościowych finansujących te kampanie, mogą uczestniczyćc $c^{38}$ :

- profesjonalni inwestorzy indywidualni (sophisticated investors), tj. posiadający odpowiedni kapitał i doświadczenie do inwestowania,

${ }^{36}$ Financial Conduct Authority (FCA) jest obok Prudential Regulatory Authority (PRA) jednym $\mathrm{z}$ dwóch brytyjskich regulatorów finansowych.

${ }^{37}$ Obostrzenia dotyczące papierów wartościowych określanych mianem Non-Readily Realisable Securities (NRRS).

${ }_{38}$ Na podstawie FCA Consultation Paper (CP18/20), 2018, https://www.fca.org.uk/publication/consultation/cp18-20.pdf/ [dostęp: 28 listopada 2018 r.]. 
- majętni inwestorzy indywidualni (high-net-worth investors),

- indywidualni inwestorzy, którzy przed otrzymaniem oferty potwierdzą, że otrzymają w odniesieniu do tej oferty profesjonalne doradztwo finansowe na regulowanych zasadach,

- indywidualni inwestorzy, którzy potwierdzą, że nie zainwestowali (i nie zainwestują) więcej niż 10\% wartości swojego portfela inwestycyjnego $\mathrm{w}$ nienotowane papiery wartościowe.

Powyższe regulacje stanowią uzupełnienie przepisów ogólnych o usługach i rynkach finansowych z 2000 r., tj. Financial Services and Markets Act 2000 (FSMA 2000), przeznaczone dla instrumentów związanych z finansowaniem społecznościowym, w tym z crowdfundingiem pożyczkowym i crowdfundingiem inwestycyjnym. Uzupełnione regulacje wprowadziły możliwość swobodniejszego funkcjonowania crowdfundingu inwestycyjnego, zastrzegając jednak obowiązek uzyskiwania przez operatorów platform crowdfundingowych autoryzacji FCA do prowadzenia takiej działalności. Co najważniejsze jednak, uzupełnione (dedykowane) regulacje wprowadziły do brytyjskiego porządku prawnego specjalną kategorię papierów wartościowych, która ma na celu m.in. legitymizację funkcjonowania na rynku rozdrobnionych praw udziałowych, które inwestorzy crowdfundingowi otrzymują w zamian za przekazane środki, a które nie są papierami wartościowymi uczestniczącymi w regulowanym obrocie.

Regulacje ujęte w uzupełnionych przepisach FSMA 2000 są też dopełnieniem tzw. Seed Enterprise Investment Scheme (SEIS), czyli regulacji oferujących zachęty podatkowe o zakresie szerszym niż crowdfunding, wprowadzonych pod koniec 2011 r. w celu wsparcia finansowania małych przedsiębiorstw i start-upów. Regulacje SEIS oferują inwestorom, w tym inwestorom crowdfundingowym, ulgi i zwolnienia podatkowe m.in. pod warunkiem ograniczenia maksymalnej rocznej kwoty inwestycji ${ }^{39}$. Zaletą takiego zestawu regulacji wydaje się zapewnienie ekosystemu, który z jednej strony wspiera funkcjonowanie dodatkowego alternatywnego źródła finansowania dla małych przedsiębiorstw i start-upów, a z drugiej strony ogranicza ryzyko kredytowe i ryzyko płynności, związane z koncentracją inwestycji wśród inwestorów indywidualnych. Dlatego też można oceniać, że regulacje obejmujące crowdfunding inwestycyjny w Wielkiej Brytanii pełnią zarówno rolę ostrożnościową, jak i stymulującą.

\section{Wyniki badania}

Przegląd literatury i informacji dotyczących crowdfundingu, przegląd rynków crowdfundingu inwestycyjnego w Europie pod kątem funkcjonowania i rozwoju - wyrażonego szacowaną wielkością tego rynku w poszczególnych

39 Zob. przypis 32. 
państwach - oraz studium przypadku crowdfundingu inwestycyjnego w Wielkiej Brytanii umożliwiły identyfikację i wstępną ocenę znaczenia potencjalnych czynników warunkujących omawiane funkcjonowanie i rozwój. Są to: czynniki endogeniczne, obejmujące aspekty regulacyjne rynku inwestycyjnego finansowania społecznościowego, oraz czynniki egzogeniczne („nieregulacyjne") o charakterze makroekonomicznym i społecznym, jak również czynnik dychotomii anglosaskiego $v s$. kontynentalnego systemu finansowego gospodarki. Zidentyfikowane czynniki zostały następnie przeanalizowane na poziomie poszczególnych państw.

- Obecność dedykowanych regulacji sensu largo (czynnik 1, regulacyjny).

- Rozwój regulacji sensu stricto (czynnik 2, regulacyjny).

- Obecność zachęt fiskalnych (czynnik 3, regulacyjny).

- Wartość PKB per capita (czynnik 4, ekonomiczno-społeczny).

- Liczba ludności (czynnik 5, ekonomiczno-społeczny).

- Odsetek użytkowników internetu (czynnik 6, ekonomiczno-społeczny)

- Odsetek użytkowników płatności mobilnych (czynnik 7, ekonomiczno-społeczny).

Badanie ilościowe uwzględniające brytyjski rynek pokazuje, że najistotniejszymi ${ }^{40}$ czynnikami, zidentyfikowanymi dla całej grupy analizowanych państw, są: zachęty fiskalne, które za sprawą Wielkiej Brytanii w największym stopniu korelują z wielkością rynku crowdfundingu inwestycyjnego (współczynnik korelacji liniowej Pearsona równy 0,65), oraz liczba ludności danego rynku/ państwa (współczynnik korelacji liniowej Pearsona równy 0,53). Kolejne istot$\mathrm{ne}^{41}$ czynniki, ale o mniejszym poziomie powiązania, to: rozwój regulacji sensu stricto poświęconych inwestycyjnemu finansowaniu społecznościowemu, który jako trzeci najistotniejszy spośród badanych czynników, koreluje z wielkością tego rynku na poziomie 0,38 (współczynnik korelacji liniowej Pearsona), oraz obecność regulacji sensu largo dedykowanych crowdfundingowi, jak również stopień penetracji internetu, wykazujące powiąznie z wielkością rynku crowdfundingu inwestycyjnego na poziomie współczynnika korelacji liniowej Pearsona równego 0,34 . Natomiast odsetek użytkowników płatności mobilnych oraz, co istotne, poziom $\mathrm{PKB}$ per capita w poszczególnych państwach nie są skorelowane z wielkością rynku crowdfunding inwestycyjnego (współczynniki korelacji liniowej Pearsona statystycznie nieistotne ${ }^{42}$ ). Wyłączenie Wielkiej Brytanii z badania - z uwagi na uwarunkowania systemowe tego rynku - skutkuje natomiast w identyfikacji dwóch istotnie i pozytywnie powiązanych czynników: liczby ludności danego rynku/państwa (współczynnik korelacji liniowej Pearsona

\footnotetext{
${ }^{40}$ Czynniki istotne dla przedziału ufności 99\%, zob. tabela 2.

${ }^{41}$ Czynniki istotne dla przedziału ufności 95\%, zob. tabela 2.

${ }^{42}$ P-wartość powyżej 0,05 , zob. tabela 2.
} 
równy 0,56 ) oraz obecności regulacji sensu largo dedykowanych crowdfundingowi (współczynnik korelacji liniowej Pearsona równy 0,38). Nieuwzględnienie rynku brytyjskiego pociąga za sobą również nieintuicyjną zależność, że odsetek zadeklarowanych użytkowników płatności mobilnych jest istotnie negatywnie powiązany z wielkością rynku crowdfundingu inwestycyjnego.

Podsumowując, należy stwierdzić, że dla całej grupy analizowanych państw, 5 spośród analizowanych czynników, w tym 3 czynniki regulacyjne, w istotny sposób korelują z wielkością rynku crowdfundingu inwestycyjnego, podczas gdy 2 spośród analizowanych czynników nie są istotnie powiązane z wielkością tego rynku. Natomiast po wyłączeniu z badania Wielkiej Brytanii, 3 spośród analizowanych czynników, w tym czynnik regulacyjny, w dużym stopniu koreluje z wielkością rynku crowdfundingu inwestycyjnego. Należy jednak wskazać, że dla dokładniejszej weryfikacji współzależności między rozmiarem rynku crowdfundingu inwestycyjnego, a społecznymi czynnikami egzogenicznymi, takimi jak preferencje dotyczące stopnia i celów używania internetu oraz zaufania do płatności internetowych czy mobilnych, analizę należałoby oprzeć na sprofilowanym badaniu pierwotnym.

Na podstawie otrzymanych wyników badania wykazana została podstawa do selektywnego przyjęcia hipotezy przedstawionej we wstępie, tj. o współzależności między wielkością rynku crowdfundingu inwestycyjnego, a obecnymi w dyskusjach czynnikami, w tym o charakterze regulacyjnym. Jednoznaczną podstawę uzyskano dla najistotniejszych czynników w postaci:

- liczby ludności danego rynku oraz

- obecności dedykowanych regulacji dotyczących finansowania społecznościowego.

Natomiast niejednoznaczną podstawę, zależną od uwarunkowań systemowych modelu finansowego gospodarki, uzyskano szczególnie dla czynnika w postaci:

- komparatywnego rozwoju regulacji dotyczących inwestycyjnego finansowania społecznościowego oraz

- regulacji dotyczących zachęt fiskalnych związanych z inwestycyjnym finansowaniem społecznościowym.

Ponadto wyniki badania wskazują, że aspekty regulacyjne emanują większym poziomem korelacji (średni współczynnik korelacji liniowej Pearsona równy 0,46 lub 0,17 bez uwzględniania rynku brytyjskiego) niż egzogeniczne aspekty „nieregulacyjne”43 (odpowiednio 0,19 oraz 0,12 ).

${ }^{43}$ Egzogeniczne aspekty „nieregulacyjne” to aspekty społeczno-ekonomiczne analizowane w badaniu (PKB per capita, liczna ludności, penetracja internetu mierzona odsetkiem użytkowników oraz odsetek zadeklarowanych użytkowników płatności mobilnych). 
Tabela 2. Zestawienie wielkości poszczególnych rynków crowdfundingu inwestycyjnego względem zidentyfikowanych czynników z uwzględnieniem współzależności

\begin{tabular}{|c|c|c|c|}
\hline & [mln euro] & [0 lub 1] ${ }^{*}$ & [0 lub 0,5 lub 1$]^{* *}$ \\
\hline & $\begin{array}{l}\text { Szacunkowa } \\
\text { wielkość rynku }^{1}\end{array}$ & Dedykowane regulacje $^{2}$ & Rozwój regulacji ${ }^{3}$ \\
\hline Wielka Brytania & $>350,0$ & 1 & 1 \\
\hline Francja & $>100,0$ & 1 & 0,5 \\
\hline Szwajcaria & 49,9 & 0 & 0,5 \\
\hline Niemcy & 24 & 1 & 1 \\
\hline Hiszpania & 22 & 1 & 1 \\
\hline Holandia & 16,6 & 1 & 1 \\
\hline Finlandia & 15,5 & 1 & 1 \\
\hline Austria & 11,1 & 1 & 1 \\
\hline Szwecja & 6,5 & 0 & 0,5 \\
\hline Włochy & 5,5 & 1 & 0,5 \\
\hline Belgia & 2,5 & 1 & 0,5 \\
\hline Chorwacja & $<1,0$ & 0 & 0,5 \\
\hline Grecja & $<1,0$ & 0 & 0,5 \\
\hline Polska & $<1,0$ & 0 & 0,5 \\
\hline Czechy & $<1,0$ & 0 & 0,5 \\
\hline Estonia & $<1,0$ & 0 & 0,5 \\
\hline Bułgaria & - & 0 & 0,5 \\
\hline Cypr & - & 0 & 0,5 \\
\hline Dania & - & 0 & 0 \\
\hline Węgry & - & 0 & 0,5 \\
\hline Irlandia & - & 0 & 0,5 \\
\hline Łotwa & - & 0 & 0,5 \\
\hline Litwa & - & 1 & 0,5 \\
\hline Luksemburg & - & 0 & 0,5 \\
\hline Malta & - & 0 & 0,5 \\
\hline Portugalia & - & 1 & 0,5 \\
\hline Rumunia & - & 0 & 0,5 \\
\hline Słowacja & - & 0 & 0,5 \\
\hline Słowenia & - & 0 & 0,5 \\
\hline Łącznie & $\sim 600,0$ & & \\
\hline Współczynnik korelacji "*** & & 0,34 & 0,38 \\
\hline P-wartośćc**** & & 0,034 & 0,020 \\
\hline Łącznie (bez Wielkiej Brytanii) & $\sim 260,0$ & & \\
\hline Współczynnik korelacji"*** & & 0,38 & $\theta, 21$ \\
\hline P-wartośćc**** & & 0,023 & 0,147 \\
\hline
\end{tabular}

1 Wielkości szacunkowe na podstawie raportu Komisji Europejskiej Identifying market and regulatory obstacles to cross-border development of crowdfunding in the EU, grudzień 2017, raportu European Crowdfunding Network Review of Crowdfunding Regulation 2017 oraz raportu Uniwersytetu w Lucernie Crowdfunding Monitoring Switzerland 2017. Dla danych opublikowanych w walucie innej niż euro (Wielka Brytania, Szwajcaria) wielkości przeliczone odpowiednio na podstawie kursu walutowego 1,125 euro/funt brytyjski oraz 0,855 euro/frank szwajcarski. Gdzie - oznacza brak zidentyfikowanego rynku lub brak danych, który implikuje brak rynku. 


\begin{tabular}{|c|c|c|c|c|}
\hline [0 lub 1] $]^{*}$ & [tys. dolarów US] & [mln os.] & [\% ludności] $^{* * *}$ & [\% ludności] $^{* * *}$ \\
\hline Zachęty podatkowe ${ }^{4}$ & $\begin{array}{c}\text { PKB per } \\
\text { capita, PPP }\end{array}$ & $\begin{array}{l}\text { Liczba } \\
\text { ludności }^{6}\end{array}$ & Użytkownicy internetu ${ }^{7}$ & Płatności mobilne ${ }^{8}$ \\
\hline 1 & 43,4 & 66,0 & 94,8 & 74,0 \\
\hline 0 & 42,9 & 67,1 & 85,6 & 64,0 \\
\hline 0 & 64,8 & 8,5 & 89,4 & 73,0 \\
\hline 0 & 50,9 & 82,7 & 89,6 & 59,0 \\
\hline 0 & 38,1 & 46,6 & 80,6 & 72,0 \\
\hline 0 & 52,8 & 17,1 & 90,4 & 74,0 \\
\hline 0 & 45,0 & 5,5 & 87,7 & 77,0 \\
\hline 0 & 52,5 & 8,8 & 84,3 & 73,0 \\
\hline 0 & 50,0 & 10,1 & 91,5 & 86,0 \\
\hline 0 & 39,6 & 60,6 & 61,3 & 73,0 \\
\hline 1 & 48,1 & 11,4 & 86,5 & 75,0 \\
\hline 0 & 25,3 & 4,1 & 72,7 & - \\
\hline 0 & 28,0 & 10,8 & 69,1 & - \\
\hline 0 & 28,8 & 38,0 & 73,3 & 79,0 \\
\hline 0 & 36,4 & 10,6 & 76,5 & - \\
\hline 0 & 32,6 & 1,3 & 87,2 & - \\
\hline 0 & 20,8 & 7,1 & 59,8 & - \\
\hline 0 & 35,1 & 1,2 & 75,9 & - \\
\hline 0 & 52,2 & 5,8 & 97,0 & 89,0 \\
\hline 0 & 28,2 & 9,8 & 79,3 & - \\
\hline 0 & 75,3 & 4,8 & 82,2 & 79,0 \\
\hline 0 & 27,8 & 1,9 & 79,9 & - \\
\hline 0 & 32,4 & 2,8 & 74,4 & - \\
\hline 0 & 104,0 & 0,6 & 97,5 & - \\
\hline 0 & 39,3 & 0,5 & 77,3 & - \\
\hline 0 & 31,9 & 10,3 & 70,4 & - \\
\hline 0 & 25,8 & 19,6 & 59,5 & 79,0 \\
\hline 0 & 31,6 & 5,4 & 80,5 & - \\
\hline 0 & 34,9 & 2,1 & 75,5 & 69,0 \\
\hline 0,65 & 0,07 & 0,53 & 0,34 & $-0,18$ \\
\hline$<0,001$ & 0,364 & 0,001 & 0,036 & 0,248 \\
\hline$-0,06$ & 0,17 & 0,56 & 0,28 & $-0,54$ \\
\hline 0,375 & 0,192 & 0,001 & 0,073 & 0,019 \\
\hline
\end{tabular}

2 Dotyczy regulacji crowdfundingu sensu largo, na podstawie raportu Komisji Europejskiej Identifying market and regulatory obstacles to cross-border development of crowdfunding in the EU, grudzien 2017.

3 Dotyczy regulacji crowdfundingu inwestycyjnego, na podstawie Alternative Finance Maturity Index opublikowanego w raporcie Crowdfunding Hub Current State of Crowdfunding in Europe, 2016.

${ }_{4}$ Na podstawie raportu Komisji Europejskiej Identifying market and regulatory obstacles to cross-border development of crowdfunding in the EU, grudzień 2017, po weryfikacji aktualności w innych źródłach.

5 Na podstawie OECD Data (dla Chorwacji na podstawie World Bank Data), dane za rok 2017, ceny stałe.

${ }^{6}$ Na podstawie World Bank Data, dane za rok 2017. 
7 Na podstawie raportu Global Competitiveness Report 2017-2018, dane dla wskaźnika „Użytkownicy internetu” (filar „Gotowości technologicznej”).

8 Na podstawie Visa Digital Payments study, 2016. Dane dotyczą zadeklarowanego odsetka użytkowników płatności mobilnych dostępne dla wybranych rynków, gdzie - oznacza brak danych.

* Brak regulacji/zachęt $=0$ lub istniejące regulacje/zachęty $=1$.

** Niski komparatywny rozwój ( $w$ tym brak)=0, średni komparatywny rozwój = 0,5 lub wysoki komparatywny rozwój = 1. Komparatywność oceniana na tle rynków europejskich.

*** Na podstawie próby.

**** Współczynnik korelacji liniowej Pearsona z szacunkową wielkością rynku. Przekreślona wartość oznacza brak statystycznej istotności korelacji dla poziomu istotności co najmniej 5\% (tj. P-wartość > 0,05), spowodowanej słabą współzależnością lub niekompletnym zestawem danych. Wartości dla jednostronnych przedziałów ufności na podstawie IBM SPSS Statistics, V24.O.O.o. Jednostronne przedziały ufności wynikają z intuicyjnego założenia o stymulującym wpływie (powiązaniu) badanych czynników na wielkość rynku. Bez tego założenia interpretacja wyników badania byłyby właściwa dla dwustronnych przedziałów ufności z odniesieniem do poziomów istotności odpowiednio: $\alpha=5 \%$ i $\alpha=10 \%$ (zamiast obecnych $\alpha=1 \%$ i $\alpha=5 \%$ ). Źródło: na podstawie badań empirycznych autora z wykorzystaniem danych jak wyżej.

Zastosowana metoda desktop research, opierająca się na różnorodnych, niekontrolowanych danych wtórnych, może, według niektórych autorów, obarczać analizę ewentualnym ryzykiem bezzasadnej interpretacji ${ }^{44}$. Zdaniem autora należy jednak ocenić, że uzyskane wyniki przeprowadzonego badania nie budzą kontrowersji interpretacyjnych.

\section{Wnioski dla Polski}

W Polsce liczba ludności, tj. jeden z dwóch najistotniejszych czynników powiązanych z rozwojem rynków crowdfundingu inwestycyjnego w Europie, jest znacznie powyżej średniej europejskiej. Fakt, że Polska jest dużą gospodarką, oferuje teoretyczne korzyści skali dla rozwoju inwestycyjnego finansowania społecznościowego, na których brak eksperci wskazują np. w przypadku Szwajcarii $^{45}$. W rezultacie obserwowany marginalny rozmiar rynku crowdfundingu inwestycyjnego w Polsce może wydawać się mało intuicyjny, zwłaszcza że jest to jedyne duże państwo, w którym wielkość tego rynku jest niewielka. Na podstawie wyników przeprowadzonego badania nie należy takiego stanu rzeczy wiązać z relatywnie umiarkowaną zasobnością Polaków. Wyniki tego badania pozwalają natomiast przypuszczać, że powodem obserwowanej sytuacji w Polsce może być brak odpowiednich, dedykowanych regulacji, które - jako istotny zidentyfikowany w badaniu czynnik - mogłyby uprawdopodobnić potencjalny rozwój polskiego rynku crowdfundingu inwestycyjnego. Należy przyjąć, że od-

${ }^{44}$ C.J. Cowton, The Use of Secondary Data in Business Ethics Research, „Journal of Business Ethics" 1998, nr 17(4), s. 423-434, https://doi.org/10.1023/A:1005730825103/.

45 Zob. przypis 18. 
powiednie, dedykowane regulacje to precyzyjne przepisy ogólne lub przepisy szczególne, które mają na celu legitymizację zjawiska crowdfundingu lub systemową stymulację jego funkcjonowania.

Można polemizować, że polskie regulacje dopuszczają i regulują rynek crowdfundingu inwestycyjnego poprzez przepisy ustawy o ofercie publicznej ${ }^{46}$. Zwłaszcza że po ostatniej nowelizacji ustawa dopuszcza (od 21 kwietnia 2018 r.) emisje „bezprospektowe” o wartości do $1 \mathrm{mln}$ euro, co może ożywić rozwój rynku inwestycyjnego finansowania społecznościowego. Autor uważa jednak, że jest to jedynie ewentualny fragmentaryczny impuls po stronie emitentów („kapitałobiorców”), a nie dedykowana regulacja. Obecne regulacje w Polsce nie sankcjonują wprost kwestii specyficznych dla crowdfundingu inwestycyjnego, jak np. zasad funkcjonowania platform crowdfundingowych i nadzoru nad operatorami takich platform ${ }^{47}$. Nie sankcjonują także kwestii istotnych z punktu widzenia inwestorów $\mathrm{z}$, internetowego tłumu”, jak np. ulgi podatkowe w obszarze zysków kapitałowych z tytułu podejmowania podwyższonego ryzyka, którego systemowym celem jest finansowanie i wspieranie innowacji. Obowiązujące regulacje nie poruszają również kwestii systemowego bezpieczeństwa rynku (np. poprzez ustawowe limity ekspozycji dla crowdfundingowych inwestorów indywidualnych, które minimalizowałyby ryzyko koncentracji).

Powyższe wnioski wywołują dwa pytania, na które należałoby odpowiedzieć z perspektywy ustawodawcy i nadzoru finansowego. Po pierwsze, co konkretnie oznacza pojęcie „odpowiednie dedykowane regulacje”. Po drugie, dlaczego uprawdopodobniać potencjalny rozwój rynku crowdfundingu inwestycyjnego w Polsce. Wydaje się, że rozwinięcia odpowiedzi na pierwsze pytanie warto poszukiwać przez analizę największego rynku crowdfundingu inwestycyjnego w Europie, tj. Wielkiej Brytanii. Tam usankcjonowana możliwość oferowania inwestorom indywidualnym rozdrobnionych udziałowych papierów wartościowych poprzez platformy crowdfundingowe bez powszechnie obowiązujących obostrzeń (pod określonymi warunkami), połączona z ulgami podatkowymi oraz limitami dla inwestorów indywidualnych, które ograniczają ryzyko koncentracji, wydaje się tworzyć korzystny ekosystem. Korzystność tego ekosystemu regulacyjnego wynika z jego dwojakiej roli - ostrożnościowej i prorozwojowej. Jeżeli chodzi o drugie pytanie, to kierunkową podpowiedzią dla tej kwestii może być zagadnienie potencjału finansowania społecznościowego w modelu

${ }^{46}$ Ustawa z 29 lipca 2005 r. o ofercie publicznej i warunkach wprowadzania instrumentów finansowych do zorganizowanego systemu obrotu oraz o spółkach publicznych, Dz.U. nr 184, poz. 1539, ze zm.

${ }^{47}$ Wskazaną kwestię mogą w przyszłości sankcjonować zapowiadane regulacje unijne, tj. wniosek (projekt) dotyczący rozporządzenia Parlamentu Europejskiego i Rady w sprawie europejskich dostawców usług w zakresie finansowania społecznościowego dla przedsiębiorstw [COM/2018/0113 final - 2018/048 (COD)]. Nie ma natomiast pewności co do ostatecznego kształtu i terminu wprowadzenia takich regulacji. 
inwestycyjnym do finansowania przedsiębiorczości, w tym do finansowania innowacji. Pomimo oczekiwań ekspertów w Polsce i za granicą co do ważności roli crowdfundingu w finansowaniu innowacyjnych przedsiębiorstw ${ }^{48}$, nie ma pewności, czy crowdfunding inwestycyjny mógłby stać się istotnym źródłem takiego finansowania w Polsce, szczególnie ze względu na bankowy charakter polskiego systemu finansowego. Ale biorąc pod uwagę, że pożądane kierunki rozwoju gospodarczego Polski to m.in. zwiększenie roli innowacji w tworzeniu polskiego $\mathrm{PKB}^{49}$, zasadna wydawałaby się dyskusja i praca nad takim potencjałem. Nawet zakładając, że potencjał inwestycyjnego finansowania społecznościowego w Polsce okazałby się ostatecznie niewielki, skutkując niewielką podażą kapitału lub niewielkim popytem na ten kapitał, nie należy zakładać braku ewentualnych korzyści wizerunkowych płynących z kampanii crowdfundingowych ${ }^{50} \mathrm{dla}$ polskiej przedsiębiorczości, $\mathrm{w}$ tym polskich innowacji.

\section{Podsumowanie}

Identyfikując najistotniejsze czynniki korelujące z rozwojem rynku crowdfundingu inwestycyjnego, tj. liczbę ludności i obecność dedykowanych regulacji, wykazano również, że Wielka Brytania jest jednoznacznie największym rynkiem crowdfundingu inwestycyjnego w Europie. W jego przypadku obecność regulacji, $w$ tym zachęt fiskalnych, oraz dużą populację należy postrzegać jako stymulanty rozwoju tego rynku. Można przypuszczać, że atrakcyjność brytyjskiego ekosystemu regulacyjnego dla crowdfundingu inwestycyjnego wynika z jego dwojakiej roli - ostrożnościowej i prorozwojowej. Poza Wielką Brytanią regulacje dotyczące crowdfundingu obowiązywały (na koniec roku 2017) także w 10 innych państwach UE, które reprezentują razem z Wielką Brytanią ponad 90\% całego łącznego rynku crowdfundingu inwestycyjnego w UE i Szwajcarii. Poza tą grupą państw jest Polska, która z liczbą ludności ok. 38 mln okazuje się jedynym dużym państwem w Europie, w którym wielkość rynku finansowania społecznościowego w modelu inwestycyjnym jest śladowa.

Na podstawie wyników przeprowadzonego badania autor potwierdził istnienie podstaw do selektywnego przyjęcia hipotezy o współzależności między wielkością rynku crowdfundingu inwestycyjnego w poszczególnych państwach

${ }^{48}$ K. Kozioł-Nadolna, Funding Innovation in Poland through Crowdfunding, ,Journal of Entrepreneurship, Management and Innovation" 2016, t. 12, nr 3, 2016, s. 7-29; European Commission, Science, Research and Innovation Performance of the EU 2018. Strengthening the Foundations for Europe's Future, Brussels 2018, https://doi.org/10.2777/14136/.

49 Uchwała nr 8 Rady Ministrów z 14 lutego 2017 r. w sprawie przyjęcia „Strategii na rzecz odpowiedzialnego rozwoju do roku 2020 (z perspektywą do 2030 r.)”, M.P. poz. 260.

50 T.E. Brown, E. Boon, L.F. Pitt, Seeking funding in order to sell: Crowdfunding as a marketing tool, „Business Horizons” 2017, t. 60, nr 2, s. 189-195, https://doi.org/10.1016/j.bushor.2016.11.004/. 
Europy a obecnymi w przedmiotowych dyskusjach czynnikami - w tym o charakterze regulacyjnym. Ponadto wyniki badania wskazują, że aspekty regulacyjne emanują większym średnim poziomem korelacji z wielkością rynków crowdfundingu inwestycyjnego niż czynniki „nieregulacyjne”, takie jak PKB per capita, odsetek użytkowników internetu czy liczba ludności państwa. Niemniej liczba ludności okazuje się drugim najistotniejszym czynnikiem, po zachętach fiskalnych, powiązanym $\mathrm{z}$ wielkością rynku inwestycyjnego finansowania społecznościowego. Stąd też istotność poszczególnych czynników i ich wartość dla Polski pozwala przypuszczać, że powodem marginalnej wielkości rynku crowdfundingu inwestycyjnego w Polsce może być brak odpowiednich regulacji, w tym brak mechanizmów o charakterze zachęt podatkowych, które mogłyby uprawdopodobnić potencjalny rozwój polskiego rynku crowdfundingu inwestycyjnego. Jest to główny wniosek o charakterze wskazówki (rekomendacji) dla legislacji i nadzoru finansowego w zakresie rozwiązań wspierających rozwój tego rynku. To, czy taki rynek należy rozwijać w Polsce, pozostaje jednak pytaniem otwartym, na które powinno się poszukiwać odpowiedzi z uwzględnieniem dwóch biegunów:

- po pierwsze, elementów ryzyka związanego z crowdfundingiem inwestycyjnym, w szczególności ryzyka „pozainwestycyjnego”, jak np. asymetria informacji, oszustwa, wyłudzenia czy cyberprzestępczość,

- po drugie, potencjału crowdfundingu inwestycyjnego do finansowania polskiej przedsiębiorczości, $w$ tym do finansowania innowacji, jak również potencjału korzystnych efektów wizerunkowych dla polskich przedsiębiorców i innowatorów, mogących płynąć z kampanii crowdfundingowych.

\section{Bibliografia}

Brown T.E., Boon E., Pitt L.F., Seeking funding in order to sell: Crowdfunding as a marketing tool, „Business Horizons” 2017, t. 60, nr 2, https://doi.org/10.1016/j.bushor.2016.11.004/.

Carvajal M., García-Avilés J.A., González J.L., Crowdfunding and non-profit media, „Journalism Practice” March 2012, https://doi.org/10.1080/17512786.2012.667267/.

Cowton C.J., The Use of Secondary Data in Business Ethics Research, „Journal of Business Ethics" 1998, nr 17(4), https://doi.org/10.1023/A:1005730825103/.

Crowdfunding Hub, Current State of Crowdfunding In Europe, Amsterdam 2016, http:// www.crowdfundinghub.eu/the-current-state-of-crowdfunding-in-europe/.

Dziuba D.T., Rozwój systemów crowdfundingu - modele, oczekiwania i uwarunkowania, „Problemy Zarządzania” 2012, nr 10(3).

Ertz M., Durif F., Arcand M., A conceptual perspective on collaborative consumption, „AMS Rev" 2018, nr 7, https://doi.org/10.1007/s13162-018-0121-3/.

European Commission, Identifying market and regulatory obstacles to cross-border development of crowdfunding in the EU, Brussels 2017. 
European Commission, Science, Research and Innovation Performance of the EU 2018. Strengthening the Foundations for Europe's Future, Brussels 2018, https://doi. org/10.2777/14136/.

European Crowdfunding Network, Review of Crowdfunding Regulation 2017, Brussels 2017.

Financial Conduct Authority, Consultation Paper (CP18/20), London 2018, https://www. fca.org.uk/publication/consultation/cp18-20.pdf/.

Kozioł-Nadolna K., Funding Innovation in Poland through Crowdfunding, „Journal of Entrepreneurship, Management and Innovation" 2016, t. 12, nr 3.

Miller D., E-Commerce Is To Borders As Crowdfunding Is To Wall Street, „Forbes” 16 marca 2015 r., https://www.forbes.com/sites/theyec/2015/03/16/e-commerce-is-to-borders-as-crowdfunding-is-to-wall-street/\#7f1f6cfa1f29/.

Miller M., Financial Innovation: The Last Twenty Years and the Next, „Journal of Financial and Quantitative Analysis" 1986, nr 21(4), https://doi.org/10.2307/2330693/.

Nesta, Crowdfunding and alternative finance in the UK, London 2017, https://www. gov.scot/binaries/content/documents/govscot/publications/minutes/2017/10/ expert-advisory-panel-on-the-collaborative-economy-august-2017/documents/ f9424fc5-ae97-4454-87b6-669e36602f13/f9424fc5-ae97-4454-87b6-669e36602f13/ govscot\%3Adocument/.

Oxera, Crowdfunding from an investor perspective, Oxford 2015.

PwC, Financial Services Technology 2020 and Beyond: Embracing Disruption, 2016, https://www.pwc.com/gx/en/financial-services/assets/pdf/technology2020-and-beyond.pdf/.

Serwicka I., Tamberi N., Not Backing Britain: Brexit vote has reduced foreign direct investment to the UK by 19 per cent, „UK Trade Policy Observatory” z 31 października 2018 r., http://blogs.sussex.ac.uk/uktpo/2018/11/01/brexit-vote-has-reduced-foreign-direct-investment-to-the-uk-by-19-per-cent/.

Technavio, Global Crowdfunding Market 2017-2021, London 2017.

Torchała A., Equity crowdfunding dla początkujących, „Puls Biznesu” z 25 października 2018 r., https://www.pb.pl/equity-crowdfunding-dla-poczatkujacych-943696/.

Williams-Grut O., The 20 biggest crowdfunding campaigns of 2017, „Businessinsider. com” 31 grudnia 2017 r., https://www.businessinsider.com/20-biggest-crowdfunding-campaigns-of-2017-2017-12? IR=T/.

University of Cambridge, The $5^{\text {th }}$ UK Alternative Finance Industry Report, Cambridge 2018, https://www.jbs.cam.ac.uk/fileadmin/user_upload/research/centres/alternative-finance/downloads/2018-5th-uk-alternative-finance-industry-report.pdf/.

University of Lucerne, Crowdfunding Monitoring Switzerland 2017, Lucerne 2018.

Vismara S., Equity Retention and Social Network Theory in Equity Crowdfunding, „SSRN Electronic Journal" September 2015, https://doi.org/10.2139/ssrn.2654325/.

Vulkan N., Astebro T., Fernandez Sierra M., Equity crowdfunding: A new phenomena, „Journal of Business Venturing Insights” 2016, t. 5.

World Economic Forum, The Global Competitiveness Report 2017-2018, Geneva 2017. 


\section{Akty prawne}

Ustawa z 29 lipca 2005 r. o ofercie publicznej i warunkach wprowadzania instrumentów finansowych do zorganizowanego systemu obrotu oraz o spółkach publicznych, Dz.U. nr 184, poz. 1539, ze zm.

Uchwała nr 8 Rady Ministrów z 14 lutego 2017 r. w sprawie przyjęcia „Strategii na rzecz odpowiedzialnego rozwoju do roku 2020 (z perspektywą do 2030 r.)”, M.P. poz. 260.

\section{Źródła internetowe}

ECB Statistical Data Warehouse, https://sdw.ecb.europa.eu.

HMRC Guidance, https://www.gov.uk/government/publications/seed-enterprise-investment-scheme-income-tax-and-capital-gains-tax-reliefs-hs393-self-assessment-helpsheet/hs393-seed-enterprise-investment-scheme-income-tax-and-capital-gains-tax-reliefs-2017.

OECD Data, https://data.oecd.org/gdp/gross-domestic-product-gdp.htm.

Office for National Statistics, Migration Statistics Quarterly Report: November 2018, https://www.ons.gov.uk/peoplepopulationandcommunity/populationandmigration/ internationalmigration/bulletins/migrationstatisticsquarterlyreport/november2018. Visa Digital Payments study, 2016, https://www.visaeurope.com/media/pdf/40172.pdf. World Bank Data, https://data.worldbank.org. 